\title{
Cell-Surface Expression of Immunoglobulin G Receptors on the Polymorphonuclear Leukocytes and Monocytes of Extremely Premature Infants ${ }^{1}$
}

\author{
NATHANIEL R. PAYNE, JOY FRESTEDT, NANCY HUNKELER, ${ }^{2}$ AND RICHARD GEHRZ \\ Departments of Neonatology, Minneapolis Children's Medical Center, Minneapolis, Minnesota 55404 [N.R.P.,
} J.F., N.H.]; and The Biomedical Research Institute, St. Paul, Minnesota 55102 [R.G.]

\begin{abstract}
This study measured Fc gamma receptor (FcR) expression on polymorphonuclear leukocytes (PMN) and monocytes from extremely premature infants. Flow cytometry was used to quantitate FcRIII [cluster of differention (CD) 16], FcRII (CD32), FcRI (CD64), CD14, and CD67 proteins on the PMN surface. Sixty-four premature infants with a mean gestational age $\pm \mathrm{SD}$ of $26 \pm$ 2 wk (birth weight $=847 \pm 217 \mathrm{~g}$ ), 12 infants born at term (gestational age $=38 \pm 1 \mathrm{wk}$ ), and 37 adults were studied. Premature infants' PMN expressed less FcRIII, measured as mean log channel fluorescence (MCF), than did term infants or adults $(\mathrm{MCF}=4.7 \pm 1.4,6.1 \pm 1.0$, and $8.8 \pm$ 1.8 , respectively, $p<0.050$ ). Premature infants also had a lower proportion of FcRIII-positive PMN than term infants or adults (mean $\pm \mathrm{SEM}=0.83 \pm 0.02$ versus $0.92 \pm$ 0.04 and $0.96 \pm 0.01$, respectively, $p<0.050)$. FcRIII expression on PMN was positively associated with cell isolation procedures $(p=0.004)$, birth weight $(p=0.004)$, and postnatal age $(p=0.032)$. Premature infants also had lower PMN expression of FcRII when compared with adults and term infants $(\mathrm{MCF}=2.4 \pm 0.6$ versus $3.0 \pm 0.7$ and 3.1 $\pm 0.3, p<0.050$ ). Both premature and term infants had fewer FcRII positive PMN than did adults (mean \pm $\mathrm{SEM}=0.90 \pm 0.09$ and $0.89 \pm 0.07$ versus $0.99 \pm 0.00$, $p<0.050$ ). Premature infants' monocytes also expressed significantly less FcRIII (MCF $=2.4 \pm 0.6$ versus $3.4 \pm$ $0.9, p=0.047)$ and FcRII $(2.1 \pm 0.5$ versus $2.9 \pm 0.6, p=$ 0.01) compared with adults. We conclude that extremely premature infants have decreased expression of FcRIII and FcRII on both their PMN and monocytes when compared with adults. The decrease in PMN FcRIII expression appears related to birth weight and chronologic age. (Pediatr Res 33: 452-457, 1993)
\end{abstract}

\section{Abbreviations}

BW, birth weight

CD14, cluster of differentiation antigen number 14

CD67, cluster of differentiation antigen number 67

$\mathrm{FcR}$, receptor for the $\mathrm{Fc}$ portion of IgG

FcRI, FcR type I (CD64)

FcRII, FcR type II (CD32)

FcRIII, FcR type III (CD16)

Received May 26, 1992; accepted December 18, 1992.

Correspondence and reprint requests: Dr. Nathaniel R. Payne, Department of Neonatology, Minneapolis Children's Medical Center, 2525 Chicago Ave. South Minneapolis, MN 55404.

Supported by grants from the Jorgen Rodgers Hoff Fund and the F. A. Bean Education and Research Fund of the Minneapolis Children's Foundation (N.R.P.). Presented, in part, at the Society for Pediatric Research annual meeting in New Orleans, LA in May 1991.

${ }^{2}$ Current address: Shell Development Company, Westhollow Research Center P.O. Box 1380, Houston, TX 77251 .
GPI, glycosyl-phosphatidylinositol

IVIG, i.v. administered IgG

MCF, mean log channel fluorescence

PMN, polymorphonuclear leukocyte

WBC, white blood cell count

NICU, neonatal intensive care unit

Bacterial infections, especially those caused by group B streptococci, continue to be a major cause of neonatal morbidity and mortality, particularly among low-birth-weight infants (1-3). Because PMN are essential for effective host defense against bacterial infections (4) and PMN function in neonates is abnormal $(5,6)$, deficient PMN function has been suggested as a contributor to neonates' susceptibility to bacterial infections (7). One possible explanation for deficient PMN function is decreased expression of cell-surface receptors on the PMN of neonates compared with those of adults (8-11). Cell-surface receptors are essential for PMN to respond to mediators of inflammation and to recognize, engulf, and destroy pathogenic bacteria (12-16).

There are three major types of phagocytic cell-surface receptors for IgG, but only two types are generally present on the surface of PMN (17). Most numerous is FcRIII, with about 100000 receptors per adult PMN (17). FcRIII binds dimeric IgG complexes with a relatively low affinity but appears important in the phagocytosis of opsonized bacteria and some unopsonized bacteria and may be important in chemotaxis and adherence as well $(11,17)$. The other FcR on PMN is FcRII, which is present at a density of about 10000 to 40000 receptors per PMN (18). FcRII probably plays an important role in triggering the oxidative burst (18). FCRI is found primarily on monocytes and macrophages (17). FcRI has a high affinity for dimeric IgG complexes and is important in promoting antibody-dependent cellular cytotoxicity. Expression of FcRI on PMN is generally quite low but can be induced by mediators of inflammation, interferon- $\gamma$, and possibly other hormones and cytokines (18). FcR appear to play a critical role in the phagocytosis of important neonatal pathogens such as coagulase-negative staphylococci, enterococci, and group B streptococci $(12,15,16)$.

This study examined the expression of the three types of FcR that recognize IgG on the PMN and monocytes of extremely premature infants, who are most vulnerable to bacterial infections. It also identified clinical features associated with decreased PMN expression of the most numerous FcR, FcRIII, and measured the PMN expression of proteins CD14 and CD67, which, like FcRIII, are attached to the cell membrane by a GPI linkage.

\section{MATERIALS AND METHODS}

Patient and population. There were 64 extremely premature infants in this study who were admitted to the NICU of Minne- 
apolis Children's Medical Center, had a BW of $<1250 \mathrm{~g}$, had a satisfactory blood specimen ( $\geq 100 \mu \mathrm{L}$; range, 100 to $500 \mu \mathrm{L}$ ) obtained during the first $10 \mathrm{~d}$ after birth (median, $3 \mathrm{~d}$; range, 1 to $10 \mathrm{~d}$ ), and whose PMN were examined for at least one type of FcR. Premature infants had a mean BW of $847 \pm 217 \mathrm{~g}$ with a median of $845 \mathrm{~g}$ (range, 480 to $1234 \mathrm{~g}$ ) and a mean gestational age of $26 \pm 2$ wk with a median of 26 wk (range, 22 to $31 \mathrm{wk}$ ). The 64 premature infants ( 30 females) included in this study were generally inborn (61 of $64,95 \%)$, received pulmonary surfactant (Survanta, Abbott Laboratories, Chicago, IL) in 62 of 64 cases $(97 \%)$, and survived at least $28 \mathrm{~d}$ in 61 of 64 cases $(95 \%)$.

The 12 term infants (gestational age $\geq 37 \mathrm{wk}$ ) were also admitted to the NICU during the study period and were sampled within $10 \mathrm{~d}$ of birth. They had a mean BW of $3483 \pm 519 \mathrm{~g}$ with a median of $3562 \mathrm{~g}$ (range, 2514 to $4330 \mathrm{~g}$ ) and a mean gestational age of $38 \pm 1$ wk with a median of 38 wk (range, 37 to 40 wk). They had the following diagnoses: congenital heart disease $(n=8)$, meconium aspiration $(n=1)$, myelomeningocele $(n=$ $1)$, hydronephrosis $(n=1)$, and pneumothorax $(n=1)$. Expression of one or more PMN receptors was also examined in 37 healthy adult volunteers. Eleven premature infants had followup evaluations (sample volume, 100 to $500 \mu \mathrm{L}$ ) at least $10 \mathrm{~d}$ after their initial sampling (median, $29 \mathrm{~d}$; range 11 to $73 \mathrm{~d}$ ). Informed consent was obtained from all participants in this study, their parents, or guardians except in the case of waste blood remaining after routine hematologic testing; waste blood was used anonymously. This project was approved by the Minneapolis Children's Medical Center Institutional Review Board for the Protection of Human Subjects.

Specimen and clinical data collection. Specimens were obtained through indwelling vascular catheters or by heelstick and were anticoagulated with EDTA. BW, estimated gestational age (based on physical exam), gender, chronologic age, 5-min Apgar scores, eosinophil count, immature PMN count, route of delivery (vaginal or cesarean), presence of maternal chorioamnionitis (based on maternal findings or placental histology), WBC, and absolute neutrophil count on the day of specimen collection, ventilator settings, arterial blood pressure at the time of specimen collection, and the results of initial blood cultures were recorded for each infant.

Isolation of PMN and monocytes from whole blood. PMN and monocytes were usually stained in whole blood. In selected experiments, PMN were isolated by layering up to $1 \mathrm{~mL}$ of whole blood over $1 \mathrm{~mL}$ of cold Isolymph (Gallard-Schlesinger, Carle Place, NY) and centrifuging at $400 \times g$ for $30 \mathrm{~min}$ at $4^{\circ} \mathrm{C}$. The red blood cell/PMN pellet was washed and resuspended in PBS to the original volume. White blood cells remaining after these procedures were $95 \pm 3 \%$ PMN as determined by light microscopy.

Monocytes were partially purified using the same procedure, except that the mononuclear cell layer was retained, washed, and stained with MAb. Mononuclear cell preparations contained 4 $\pm 4 \%$ PMN by examination of slides prepared by cytocentrifuging samples onto glass slides. Ninety-two $\pm 11 \%$ of the mononuclear cells identified as monocytes by small- and right-angle light scatter were confirmed to be monocytes by MY9 staining and flow cytometry analysis.

$M A b$ and cell staining. FITC-conjugated MAb 3G8 (IgG1 subtype, anti-FcRIII), IV.3 (IgG2b, anti-FcRII), and 32.2 (IgG1, anti-FcRI) were obtained from Medarex (West Lebanon, NH); 80H13 (IgG1, anti-CD67), from AMAC (Westbrook, ME); and 322A-1 (IgG2b, anti-CD14) and phycoerythrin-conjugated MY9 (IgG2b, anti-monocyte), from Coulter Laboratories (Hialeah, FL). FITC-conjugated or phycoerythrin-conjugated control MAb directed against irrelevant antigens but with matching isotypes were purchased from Coulter (IgG1, IgG2b). FcR MAb $(20 \mu \mathrm{g} /$ $\mathrm{mL})$, anti-CD67 $(20 \mu \mathrm{g} / \mathrm{mL})$, anti-MY9 $(1 \mu \mathrm{g} / \mathrm{mL})$, or anti-CD14 $(1 \mu \mathrm{g} / \mathrm{mL})$ was added to 50 to $100 \mu \mathrm{L}$ of blood according to the manufacturers' directions. The same concentrations were used to stain with the irrelevant control MAb. After a 30-min incubation at $4^{\circ} \mathrm{C}$, the red blood cells were lysed and the PMN fixed using Immuno-Prep (Coulter) according to the manufacturer's directions.

Flow cytometric evaluation. All specimens were examined on an EPICS PROFILE II flow cytofluorometer (Coulter). PMN and monocyte data were selected, and 5000 cells were analyzed by flow cytometry. Other cells were excluded from subsequent analysis based on small- and right-angle light scatter. Standardization of fluorescence was performed daily using fluorescent microbeads (Standard-Brite beads, Coulter). Control samples included neonates' and adults' PMN stained with the isotypematched, control MAb. Results from samples stained with control MAb were used to exclude from analysis $\geq 98 \%$ of nonspecifically stained cells. The resulting receptor expression was measured as cell-surface fluorescence intensity and is reported as MCF on a four-decade $\log$ scale. The proportion of fluorescencepositive cells and examination of the actual fluorescence histograms were used to evaluate cell-surface antigen expression.

To evaluate release of FcRIII antigen, some specimens were examined immediately, stored at $4^{\circ} \mathrm{C}$ for over $3 \mathrm{~h}$, and reexamined. These samples had very similar FcRIII expression before and after storage $(\mathrm{MCF}=8.8 \pm 1.0$ versus $8.7 \pm 1.0, n=2$ adults and $\mathrm{MCR}=4.0 \pm 0.5$ versus $4.0 \pm 0.9, n=4$ premature infants).

Statistical analysis. Results from multiple specimens obtained from the same adult and stained with the same MAb on different days were averaged. Differences in MCF and the proportion of FcRIII- or FcRII-positive cells among specimens from adults and premature and term infants were evaluated using a one-way analysis of variance with Scheffe's test for multiple comparisons. Examination of differences between samples prepared with and without PMN isolation procedures was performed with paired $t$ test. Other comparisons between two sample groups were performed using independent, two-tailed $t$ tests. Multivariate analysis was performed with multiple linear regression to examine the association of clinical features with FcRIII and FcRII expression. Measures of dispersion about the mean are presented as mean \pm SD unless otherwise noted. A $p$ value $<0.050$ was considered significant. Commercial software (SPSS, Inc, Chicago, IL or MacSS, Statsoft, Tulsa, OK) was used for all calculations.

\section{RESULTS}

FCRIII expression on PMN. Premature infants expressed significantly less FcRIII on their PMN than did adults (Table 1). FcRIII expression per PMN of term infants was intermediate between that of premature infants and adults (Table 1). Figure 1 shows representative histograms from anti-FcRIII staining of a premature neonate's and an adult's PMN. Premature infants' cell fluorescence histograms were wider than those obtained from adults' PMN and suggested that FCRIII antigen expression on premature infants' PMN was not only decreased but also more variable from cell to cell than that on adults' PMN.

The proportion of PMN that stained positively for FcRIII was also lower in premature infants than in term infants or adults (Table 1). The $95 \%$ confidence intervals for the proportion of FcRIII-positive PMN from premature infants did not overlap those from adults (Table 1). These results indicated that premature infants had fewer PMN expressing detectable FcRIII antigen and less FcRIII antigen per PMN when compared with either adults or term infants.

FCRIII expression on partially purified PMN. To validate the whole-blood staining technique, we compared FcRIII expression in premature infants and adults after PMN staining in partially purified cell suspensions or in whole blood. PMN purification procedures significantly increased FcRIII expression on the PMN of both premature infants and adults (Table 2). However, as in whole-blood samples, FcRIII expression on isolated PMN remained significantly lower in premature infants than adults, and the proportion of FcRIII-positive cells among isolated PMN also 
Table 1. FCRIII and FCRII antigen expression on PMN of adults and term and premature infants*

\begin{tabular}{|c|c|c|c|c|}
\hline \multirow[b]{2}{*}{ Study group } & \multicolumn{2}{|c|}{ FcRIII } & \multicolumn{2}{|c|}{ FcRII } \\
\hline & $\begin{array}{c}\mathrm{MCF} \\
(\text { mean } \pm \mathrm{SD})\end{array}$ & $\begin{array}{l}\text { Proportion of positive } \\
\text { cells (mean } \pm \text { SEM, } \\
95 \% \text { confidence } \\
\text { limits) }\end{array}$ & $\begin{array}{c}\mathrm{MCF} \\
(\text { mean } \pm \mathrm{SD})\end{array}$ & $\begin{array}{l}\text { Proportion of positive } \\
\text { cells (mean } \pm \text { SEM, } \\
95 \% \text { confidence } \\
\text { limits) }\end{array}$ \\
\hline Premature infants & $\begin{array}{l}4.7 \pm 1.4 \\
(n=51) \dagger\end{array}$ & $\begin{array}{c}0.83 \pm 0.02 \\
(0.79-0.87)\end{array}$ & $\begin{array}{c}2.4 \pm 0.6 \\
(n=26)\end{array}$ & $\begin{array}{c}0.90 \pm 0.09 \\
(0.86-0.94)\end{array}$ \\
\hline Term infants & $\begin{array}{l}6.1 \pm 1.0 \\
(n=7)\end{array}$ & $\begin{array}{c}0.92 \pm 0.04 \\
(0.84-1.00)\end{array}$ & $\begin{array}{l}3.1 \pm 0.3 \\
(n=5)\end{array}$ & $\begin{array}{c}0.89 \pm 0.07 \\
(0.83-0.95)\end{array}$ \\
\hline Adults & $\begin{array}{l}8.8 \pm 1.8 \\
(n=30) \dagger\end{array}$ & $\begin{array}{c}0.96 \pm 0.01 \\
(0.94-0.98)\end{array}$ & $\begin{array}{l}3.1 \pm 0.7 \\
(n=24)\end{array}$ & $\begin{array}{c}0.99 \pm 0.01 \\
(0.98-1.00)\end{array}$ \\
\hline
\end{tabular}

* FcRIII expression on PMN from premature and term infants was significantly less than that seen in adults $(p<0.05)$. Values for FcRII expression on PMN from premature infants differed significantly from those of adults $(p<0.05)$.

$\dagger$ FcRIII expression was measured using specimens from 51 of 64 study infants and 30 of 37 adults ( 13 infants and seven adults had measurements of other FcR or FcRIII on monocytes but not FcRIII on PMN).

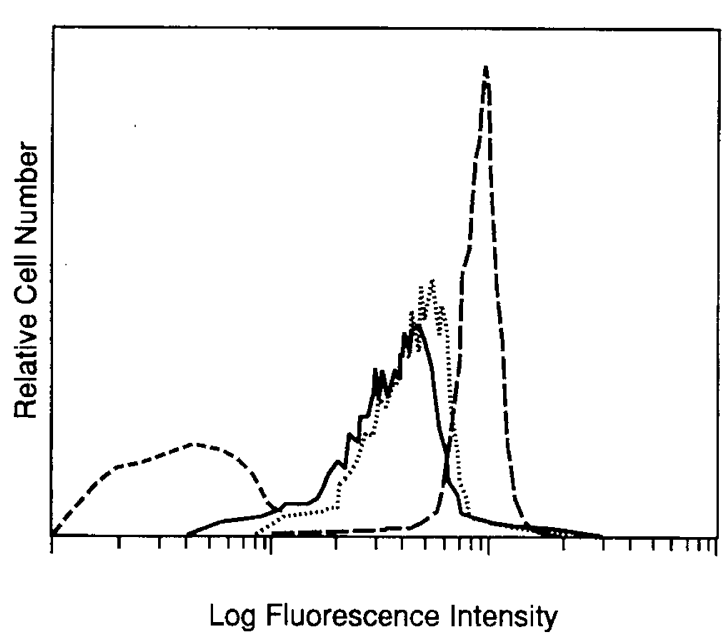

Fig. 1. Histograms from a premature infant's PMN stained with FITC-labeled anti-FcRIII (MAb 3G8, IgG1) in whole blood (-), stained in a purified preparation of PMN $(\ldots \ldots)$, histogram from an adult's PMN stained in whole blood (-_), and the adult's PMN after staining in whole blood with an isotypic control, murine MAb, directed against an irrelevant antigen (---). The abscissa indicates MCF and the ordinate shows the relative cell number.

remained lower in the premature infants than in the adults (Table 2).

Clinical and laboratory features correlating with FCRIII expression. Multivariate analysis indicated that FcRIII expression was associated with only two of the clinical features examined in this study. Together, these two features accounted for $29 \%\left(R^{2}=\right.$ 0.294 ) of the total variation in FcRIII expression. Positive asso- ciations were seen with BW $\left(R^{2}=0.135, p=0.008\right)$ and chronologic age (within the first $10 \mathrm{~d}$ ) at the time of sampling $\left(R^{2}=0.103, p=0.022\right)$. For example, patients examined at age 4 to $10 \mathrm{~d}$ had greater FCRIII expression (MCF $=5.1 \pm 1.4, n=$ 22) than did those examined on 11 to $3(\mathrm{MCF}=4.3 \pm 1.2, n=$ $29, p=0.032, t$ test). FcRIII expression also increased over time in the 11 premature infants who had followup studies (Fig. 2). However, FcRIII antigen expression rarely reached the $95 \%$ confidence limits of the adults' mean FcRIII expression (Fig. 2).

No significant correlation existed between FcRIII expression and gestational age, gender, method of delivery (vaginal versus cesarean), maternal chorioamnionitis, Apgar scores, ventilator settings (fraction of inspired oxygen, peak inspiratory pressure, mean airway pressure, and rate), blood pressure, nosocomial bacteremia, WBC, corrected WBC, absolute neutrophil count, percentage of circulating immature PMN forms, or eosinophils seen on peripheral blood smear (all $p>0.050$ ). Two patients had a positive blood culture (one each with Bacteroides fragilis and Streptococcus pneumoniae) on admission to the NICU, and both patients had FcRIII expression (MCF $=4.8$ and 8.4) greater than the mean $(\mathrm{MCF}=4.7)$ for premature infants.

Expression of FCRII on PMN. FcRII expression was significantly lower on the PMN of premature infants than on adults' or term infants' PMN (Table 1). The proportion of PMN expressing FcRII was also significantly lower in premature infants than adults (Table 1). Term infants had reduced proportions of FcRII-positive cells, although the antigen expression per FcRIIpositive cell was similar to that seen on adults' PMN (Table 1). Histograms suggested that the expression of FcRII on PMN was somewhat more variable in premature neonates than adults (Fig. 3). There was no association between FcRII expression and BW or chronologic age. Although there was no correlation between the intensity of FCRII and FcRIII expression per PMN as meas-

Table 2. FCRIII expression on PMN stained in whole blood or isolated PMN preparations

\begin{tabular}{|c|c|c|c|c|}
\hline \multirow[b]{2}{*}{ Study group } & \multicolumn{2}{|c|}{ Whole blood } & \multicolumn{2}{|c|}{ Isolated PMN } \\
\hline & $\begin{array}{c}\text { MCF } \\
(\text { mean } \pm \mathrm{SD})\end{array}$ & $\begin{array}{l}\text { Proportion FcRIII positive } \\
\text { cells (mean } \pm \text { SEM, } 95 \% \\
\text { confidence limits) }\end{array}$ & $\begin{array}{c}\text { MCF } \\
(\text { mean } \pm \mathrm{SD})\end{array}$ & $\begin{array}{l}\text { Proportion FcRIII positive } \\
\text { cells (mean } \pm \text { SEM, 95\% } \\
\text { confidence limits) }\end{array}$ \\
\hline Premature infants $(n=11)$ & $5.1 \pm 1.3$ & $\begin{array}{c}0.77 \pm 0.06 \\
(0.65-0.89) \ddagger\end{array}$ & $6.3 \pm 1.5^{* \dagger}$ & $\begin{array}{c}0.71 \pm 0.08 \\
(0.55-0.87) \ddagger\end{array}$ \\
\hline Adults $(n=8)$ & $8.3 \pm 1.3$ & $\begin{array}{c}0.96 \pm 0.02 \\
(0.92 \pm 1.00)\end{array}$ & $9.6 \pm 1.6^{*}$ & $\begin{array}{l}0.96 \pm 0.02 \\
(0.92-1.00)\end{array}$ \\
\hline
\end{tabular}

* FcRIII expression (i.e. MCF) was significantly higher on isolated PMN than on PMN stained in whole blood in both premature infants $(p=$ 0.004 , paired $t$ test $)$ and adults $(p=0.001)$.

$\dagger$ FcRIII expression on premature infants' isolated PMN was significantly less than that on adults' isolated PMN ( $p<0.001$, two-tailed, independent $t$ test).

¥The proportion of positive cells was lower in premature infants than adults both with and without PMN isolation procedures with no overlap of the $95 \%$ confidence intervals. 


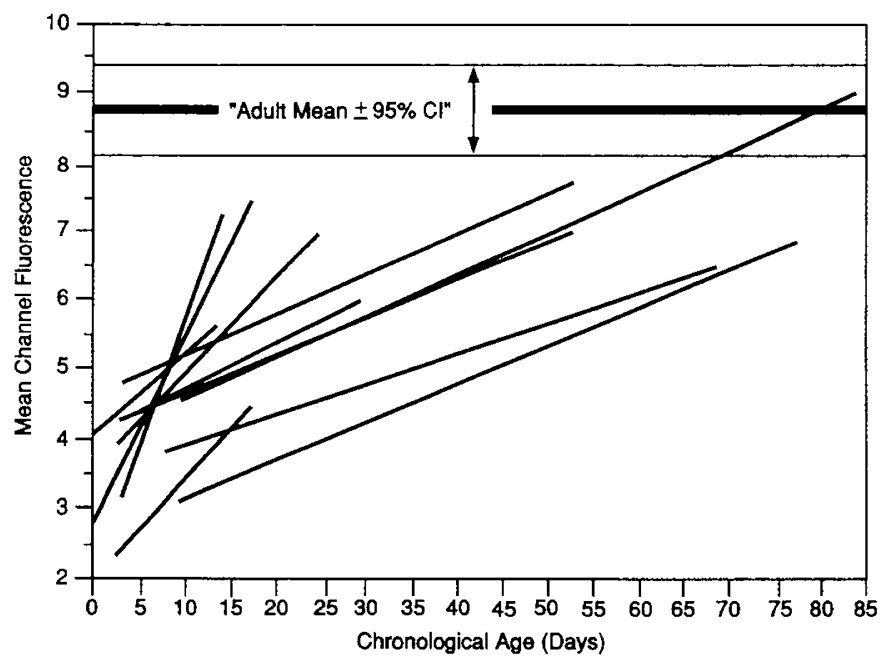

Fig. 2. Individual lines indicate the difference between initial and final followup measurements of FcRIII receptor antigen expression in 11 premature infants. Chronologic age is indicated along the absciss $a$ and MCF along the ordinate. The MCF and $95 \%$ confidence limits $(C I)$ for adult controls $(8.8 \pm 0.64)$ are shown for comparison.

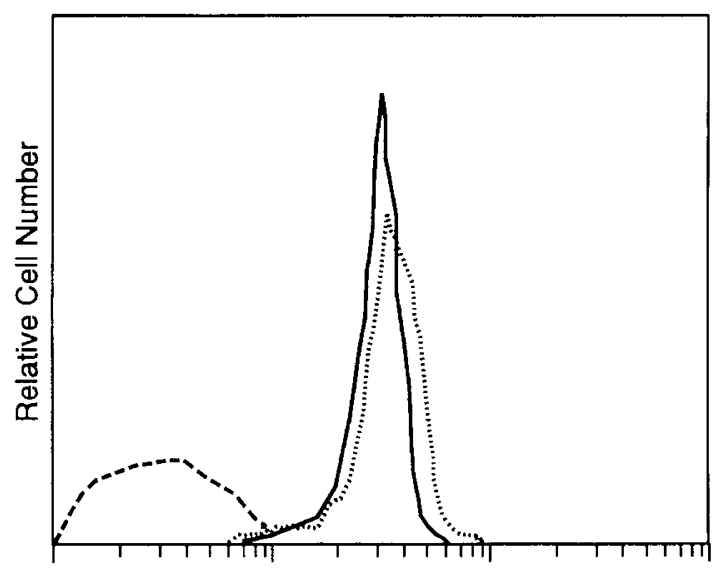

Log Fluorescence Intensity

Fig. 3. Histograms of the fluorescence after staining PMN with FITClabeled anti-FcRII (MAb IV.3, IgG2) in whole blood from a premature infant $(\ldots \ldots)$ and an adult $(-)$ and the fluorescence of the adult's PMN after staining with an isotypic control, murine MAb, directed against an irrelevant antigen (---). The abscissa indicates MCF and the ordinate shows the relative cell number.

ured by MCF $\left(R^{2}=0.005\right)$, the proportion of PMN positive for FcRII and FcRIII was significantly correlated $\left(R^{2}=0.601, p<\right.$ 0.001).

Expression of FCRI on PMN. FcRI is usually found on monocytes and macrophages rather than PMN (17). However, FcRI has been reported to be increased on PMN from patients with leukocyte adhesion deficiency (19) and after culture of PMN with interferon- $\gamma(17)$. We reasoned that FcRI might be increased on premature infants' PMN to compensate for decreased FcRIII expression. FcRI expression varied little between the PMN of adults and premature infants, except that premature infants had a greater proportion of FcRI-positive cells than did adults (Table $3)$.

Expression of other GPI-anchored proteins (CD14, CD67). FcRIII, CD14, and CD67 are anchored to the cell membrane by a GPI linkage rather than by a transmembrane attachment $(20$, 21). The expression of GPI-anchored proteins, CD14 (22) and CD67 (23), were not significantly different between premature infants and adults (Table 3). CD67 expression was greater (Table
3) on the PMN of premature infants than on those of adults; however, these changes did not reach statistical significance ( $p$ $=0.065$ ).

Expression of $F C R, C D 14$, and CD67 proteins on monocytes. To investigate whether decreased FcRIII and FcRII expression on PMN was an isolated finding or also present on other myeloid cells, we examined FcR expression on monocytes. Premature infants expressed less FcRIII and less FcRII per monocyte than did adults using whole-blood staining (Table 4). To confirm the decreased FcRIII expression on monocytes, we prepared partially purified monocyte suspensions and compared FcRIII expression with that of MY9, an antigen not expressed on mature blood cells other than monocytes. Premature infants $(n=7)$ and adults $(n=6)$ did not differ in MY9 expression (MCF $=3.3 \pm 0.9$ versus $3.2 \pm 1.1$ ), although FcRIII expression was again shown to be reduced on the monocytes of premature infants $(\mathrm{MCF}=$ $3.8 \pm 0.6$ versus $2.0 \pm 0.9, p=0.001)$

The monocyte expression of FCRI, CD14, or CD67, as expressed by MCF, did not differ between adults and premature infants (Table 4). There were significant differences between adults and infants in the proportions of monocytes staining positive for the various antigens. Premature infants had a significantly larger proportion of FcRIII- and CD67-positive monocytes than did adults but a lower proportion of FcRII-, FcRI-, and CD14-positive monocytes than adults (Table 4).

\section{DISCUSSION}

Premature infants had not only decreased FcRIII expression per PMN but also fewer PMN expressing any detectable FcRIII antigen compared with adults (Table 1). The premature infants had MCF values for FcRIII expression on PMN that were $53 \%$ of adult controls in this study compared with $63 \%$ in the study of Smith et al. (9) and 71\% in the study of Carr and Davies (10). Our data also suggested that premature infants' PMN express less FcRII $(p=0.004)$ on their PMN than adults. Carr and Davies (10) reported that FcRII expression on the PMN from premature infants was about $88 \%$ of that on adults' PMN compared with $80 \%$ of adult controls reported here.

We did not confirm Carr and Davies' (10) association between FcRIII expression and clinical variables such as sepsis and respiratory distress syndrome. Our study differed from theirs in several ways: our patient sample was larger ( $n=64$ versus 27 ), had a lower BW (median $=845$ versus $962 \mathrm{~g}$ ), was more homogenously immature (BW range $=480$ to 1234 versus 693 to 1800 g), was less likely to have early-onset bacteremia (two of $64,3 \%$ versus five of $27,19 \%$ ), and was more likely to receive pulmonary surfactant treatment. Our surfactant-treated patients rarely required high levels of ventilator support and may have been less "stressed" than those in other studies.

There are two possible explanations for decreased FcRIII expression on the PMN of premature infants. Either FcRIII production and/or transport to the cell surface is decreased or FcRIII release from the cell membrane is increased. This study found evidence to support both potential mechanisms.

In this study, FcRIII expression on the PMN of extremely premature neonates was significantly increased by PMN isolation procedures (Table 2). Cytokines also modulate FcRIII expression on the surface of PMN $(24,25)$. Because neonatal cells produce less interferon- $\gamma(26)$, granulocyte-colony-stimulating factor (27), and tumor necrosis factor (28) than adult cells, one might expect decreased FcRIII expression to be due to decreased circulating levels of cytokines. The fact that FcRII expression on PMN and FcRIII expression on monocytes are both decreased indicates that several different receptors are down-regulated and is consistent with decreased receptor production and/or transport to the cell surface.

An alternative explanation for the decreased FcRIII expression on premature infants' PMN relates to the GPI linkage attaching FcRIII to the cell membrane. This linkage permits release of 
Table 3. Expression of FCRI, CD67, and CD14 on PMN of adults and premature infants

\begin{tabular}{|c|c|c|c|c|c|c|}
\hline \multirow[b]{2}{*}{ Group } & \multicolumn{2}{|c|}{ FcRI } & \multicolumn{2}{|c|}{$\mathrm{CD} 67$} & \multicolumn{2}{|c|}{$\mathrm{CD} 14$} \\
\hline & MCF & $\begin{array}{c}\text { Proportion } \\
\text { positive }\end{array}$ & $\mathrm{MCF}$ & $\begin{array}{l}\text { Proportion } \\
\text { positive }\end{array}$ & $\mathrm{MCF}$ & $\begin{array}{l}\text { Proportion } \\
\text { positive }\end{array}$ \\
\hline Premature infants & $\begin{array}{l}1.1 \pm 0.4 \\
(n=14)\end{array}$ & $0.40 \pm 0.07^{*}$ & $\begin{array}{c}2.0 \pm 0.4 \\
(n=11)\end{array}$ & $0.88 \pm 0.04$ & $\begin{array}{c}0.8 \pm 0.3 \\
(n=11)\end{array}$ & $0.27 \pm 0.07$ \\
\hline Adults & $\begin{array}{l}1.0 \pm 0.3 \\
(n=8)\end{array}$ & $0.09 \pm 0.03$ & $\begin{array}{l}1.6 \pm 0.4 \\
(n=6)\end{array}$ & $0.85 \pm 0.08$ & $\begin{array}{l}0.6 \pm 0.3 \\
(n=6)\end{array}$ & $0.06 \pm 0.02$ \\
\hline
\end{tabular}

* Mean \pm SEM proportion of cells positive for the indicated antigen. Premature infants had significantly higher proportions of $\mathrm{FcRI}(p=0.001)$ and CD14 $(p=0.009)$ PMN compared with adults.

Table 4. Expression of FcRIII, FcRII, FcRI, CD67, and CDI4 on monocytes of adults and premature infants

\begin{tabular}{|c|c|c|c|c|c|c|c|c|c|c|}
\hline \multirow[b]{2}{*}{ Group } & \multicolumn{2}{|c|}{ FcRIII } & \multicolumn{2}{|c|}{ FcRII } & \multicolumn{2}{|c|}{ FcRI } & \multicolumn{2}{|c|}{ CD67 } & \multicolumn{2}{|c|}{$\mathrm{CD} 14$} \\
\hline & $\mathrm{MCF}^{*}$ & $\begin{array}{c}\text { Proportion } \\
\text { positive } \dagger\end{array}$ & $\mathrm{MCF}$ & $\begin{array}{c}\text { Proportion } \\
\text { positive }\end{array}$ & MCF & $\begin{array}{c}\text { Proportion } \\
\text { positive }\end{array}$ & MCF & $\begin{array}{l}\text { Proportion } \\
\text { positive }\end{array}$ & MCF & $\begin{array}{c}\text { Proportion } \\
\text { positive }\end{array}$ \\
\hline $\begin{array}{l}\text { Premature } \\
\text { infants }\end{array}$ & $\begin{array}{c}2.4 \pm 0.6 \\
(n=14)\end{array}$ & $0.41 \pm 0.03$ & $\begin{array}{c}2.1 \pm 0.5 \\
(n=7)\end{array}$ & $0.82 \pm 0.04$ & $\begin{array}{l}1.6 \pm 0.4 \\
(n=14)\end{array}$ & $0.67 \pm 0.11$ & $\begin{array}{c}1.4 \pm 0.6 \\
(n=11)\end{array}$ & $0.21 \pm 0.04$ & $\begin{array}{c}3.3 \pm 1.3 \\
(n=11)\end{array}$ & $0.63 \pm 0.03$ \\
\hline Adults & $\begin{array}{l}3.4 \pm 0.9 \\
(n=6)\end{array}$ & $0.23 \pm 0.20$ & $\begin{array}{c}2.9 \pm 0.6 \\
(n=4)\end{array}$ & $0.96 \pm 0.00$ & $\begin{array}{l}1.9 \pm 0.6 \\
(n=6)\end{array}$ & $0.87 \pm 0.05$ & $\begin{array}{l}1.1 \pm 0.4 \\
(n=5)\end{array}$ & $0.11 \pm 0.03$ & $\begin{array}{l}2.9 \pm 0.8 \\
(n=6)\end{array}$ & $0.88 \pm 0.01$ \\
\hline
\end{tabular}

* Expression of these cell surface antigens differed significantly in the case of FcRIII $(p=0.047$, two-tailed, independent $t$ test $)$ and FCRII ( $p=$ $0.010)$.

$\dagger$ Mean \pm SEM proportion of cells positive for the indicated antigen. The proportion of antigen-positive cells differed significantly between adults and premature infants for FCRII $(p=0.016)$, FCRII $(p=0.010)$, FcRI $(p<0.001), \operatorname{CD} 67(p=0.028)$, and CD14 $(p<0.001)$.

FcRIII protein in response to stimulation of PMN with N-formylmethionyl-leucyl-phenylalanine $(29,30)$, phorbol myristate acetate $(29,30)$, and other stimuli (30). Premature infants' PMN may produce normal amounts of FcRIII but release it more readily, resulting in lowered surface expression.

A generalized defect in the formation of GPI anchors seems unlikely, inasmuch as adults and premature infants did not differ in the expression of two other GPI-anchored proteins, CD 14 and CD67, on either PMN or monocytes. We also considered the possibility of FcRIII release during specimen processing. However, specimens were collected in EDTA, which effectively inhibits the release of FcRIII (30), and we saw little change in FcRIII expression by PMN after storing specimens for $3 \mathrm{~h}$ (see Materials and Methods). The possibility of in vivo release of FcRIII is still quite possible, and both decreased production/transport and increased release may combine to reduce FcRIII expression on the PMN of premature neonates.

The consequences of decreased FCRIII and FcRII expression for premature infants are not known. However, we suspect that FcRIII and FcRII are important to the phagocytosis of bacterial pathogens for several reasons. Destruction of IgG-coated platelets is reduced after administration of anti-FcRIII in patients with idiopathic thrombocytopenia (31), indicating that FcRIII is important to the in vivo phagocytosis of IgG-coated particles. Furthermore, FcRIII appears to be important to the in vitro phagocytosis of neonatal pathogens, coagulase-negative staphylococci (12), and group B streptococci (16). Therefore, reduced FcRIII expression on PMN of extremely premature infants may significantly weaken host defenses against bacterial infection and predispose infants to infection.

Reduced expression of FcRIII and FcRII may affect PMN function and the efficiency of IVIG infusion in the prevention $(32,33)$ or treatment of bacterial infections in prematurely born neonates (34). At least part of the potential effectiveness of IVIG resides in its ability to opsonize bacteria and then serve as a ligand binding the bacteria to the PMN via FCR. Deficiencies in neonates' expression of FCR may render IVIG ineffective in premature infants with low levels of FcRIII expression or, conversely, may optimize the function of the lower number of FcRIII receptors that are present on these infants' PMN.

The identification of specific defects in the host defenses of premature infants, such as reduced FcRIII and FcRII expression, should lead to a better understanding of the causes of neonates' susceptibility to bacterial infections. Elucidation of these defects may also lead to more specific and effective therapeutic innovations.

Acknowledgments. The authors thank Karin Gulbrandsen, Jean Carlson, Wendy R. Walters, and S. McCluhan for technical assistance; the hematology laboratory staff for assistance in obtaining and processing specimens; and Drs. Susan Simonton and Peggy Johnson for their support and encouragement.

\section{REFERENCES}

1. Payne NR, Burke BA, Day DL, Christenson PD, Thompson TR, Ferrieri P 1988 Correlation of clinical and pathologic findings in early onset neonatal group B streptococcal infection with disease severity and prediction of outcome. Pediatr Infect Dis J 7:836-847

2. Walsh JA, Hutchins S 1989 Group B streptococcal disease: its importance in the developing world and prospect for prevention with vaccines. Pediatr Infect Dis J 8:271-277

3. Baker CJ 1990 Immunization to prevent group B streptococcal disease: victories and vexations. J Infect Dis 161:917-921

4. Christensen RD, Rothstein G, Anstall HB, Bybee B 1982 Granulocyte transfusions in neonates with bacterial infection, neutropenia, and depletion of mature marrow neutrophils. Pediatrics 70:1-6

5. Rider ED, Christensen RD, Hall DC, Rothstein G 1988 Myeloperoxidase deficiency in neutrophils of neonates. J Pediatr 112:648-651

6. Shigeoka AO, Santos JI, Hill HR 1979 Functional analysis of neutrophil granulocytes from healthy, infected, and stressed neonates. J Pediatr 95:454460

7. Wilson CB 1986 Immunologic basis for increased susceptibility of the neonate to infection. $\mathrm{J}$ Pediatr 108:1-12

8. Bruce MC, Baley JE, Medvik KA, Berger M 1987 Impaired surface membrane expression of $\mathrm{C} 3 \mathrm{bi}$ but not $\mathrm{C} 3 \mathrm{~b}$ receptors on neonatal neutrophils. Pediatr Res 21:306-311

9. Smith JB, Campbell DE, Ludomirsky A, Polin RA, Douglas SD, Garty BZ, Harris MC 1990 Expression of the complement receptors CR 1 and CR 3 and the type III FC gamma receptor on neutrophils from newborn infants and from fetuses with Rh disease. Pediatr Res 28:120-126

10. Carr R, Davies JM 1990 Abnormal FcRIII expression by neutrophils from very preterm neonates. Blood 76:607-611

11. Masuda K, Kinoshita Y, Kobayashi Y 1989 Heterogeneity of Fc receptor expression in chemotaxis and adherence of neonatal neutrophils. Pediatr Res 25:6-10

12. Schutze GE, Edwards MS, Baker CJ 1991 Neutrophil receptors in opsonophagocytosis of coagulase-negative staphylococci. Infect Immun 59:25732578

13. Sherman MP, Johnson JT, Anderson DC, Smith CW 1990 Anti-CD18 antibody reveals the importance of neutrophils in preterm lung host defense. Pediatr Res 27:267A(abstr) 
14. Smith CL, Baker CJ, Anderson DC, Edwards MS 1990 Role of complement receptors in opsonophagocytosis of group B streptococci by adult and neonatal neutrophils. J Infect Dis 162:489-95

15. Harvey BS, Baker CJ, Edwards MS 1991 Complement and antibody activity in opsonophagocytosis of enterococci. Pediatr Res 29:282A(abstr)

16. Noya FJD, Edwards MS, Baker CJ 1991 Neutrophil Fc receptor participation in phagocytosis of group B streptococcus. Pediatr Res 29:161A(abstr)

17. Unkeless JC 1989 Function and heterogeneity of human Fc gamma receptors for immunoglobulin G. J Clin Invest 83:355-361

18. Huizinga TW, Roos D, von dem Borne AE 1990 Neutrophil Fc-gamma receptors: a two way bridge in the immune system. Blood 75:1211-1214

19. Majima T, Minegishi N, Nagatomi R, Ohashi $Y$, Tsuchiya $S$, Kobayashi $K$ Konno T 1990 Unusual expression of IgG Fc receptors on peripheral granulocytes from patients with leucocyte adhesion deficiency (CD11/CD18 deficiency). J Immunol 145:1694-1699

20. Selvaraj P, Rosse WF, Silber R, Springer TA 1988 The major Fc receptor in blood has a phosphatidylinositol anchor and is deficient in paroxysma nocturnal haemoglobinuria. Nature 333:565-567

21. Edberg JC, Salmon JE, Whitlow M, Kimberly RP 1991 Preferential expression of human Fc gamma RIII (CD16) in paroxysmal nocturnal hemoglobinuria. J Clin Invest 87:58-67

22. Griffin JD, Ritz J, Nadler LM, Schlossman SF 1981 Expression of myeloid differentiation antigens on normal and malignant myeloid cells. J Clin Invest 68:932-941

23. van der Schoot, Huizinga TWJ, Gadd S, Majdic O, Wijmans R, Knapp W, von dem Borne AEGK 1989 Identification of three novel PI-linked proteins on granulocytes. In: Knapp W, Dorken B, Gilks WR, Rieber EP, Schmid RE, Stein H, von dem Borne AEGKR (eds) Leucocyte Typing IV, White Cell Differentiation Antigens. Oxford University Press, New York, pp 887 891

24. Buckle AM, Hogg N 1989 The effect of IFN-gamma and colony-stimulating factors on the expression of neutrophil cell membrane receptors. J Immunol 143:2295-2301

25. Frestedt JL, Gehrz R, Payne NR 1992 Modulation of immunoglobulin receptors (FcRIII, FcRII) and complement receptor type 3 (CR3) on polymorphonuclear leukocytes from extremely premature infants (birthweights $<1250 \mathrm{~g}$ ) Pediatr Res 31:266A(abstr)

26. Wilson CB, Westall J, Johnston L, Lewis DB, Dower SK, Alpert AR 1986 Decreased production of interferon-gamma by human neonatal cells. J Clin Invest 77:860-867

27. Cairo M, Suen Y, Knoppel E, Dana R, Park L, Clark S, van de Ven C, Sender L 1992 Decreased G-CSF and IL-3 production and gene expression from mononuclear cells of newborn infants. Pediatr Res 31:574-578

28. English BK, Burchett SK, English JD, Ammann AJ, Wara DW, Wilson CB 1988 Production of lymphotoxin and tumor necrosis factor by human neonatal mononuclear cells. Pediatr Res 24:717-722

29. Huizinga TW, van der Schoot CE, Jost C, Klaassen R, Kleijer M, von dem Borne AE, Roos D, Tetteroo PA 1988 The PI-linked receptor FCRIII is released on stimulation of neutrophils. Nature 333:667-669

30. Huizinga TWJ, de Haas M, Kleijer M, Nuijens JH, Roos D, von dem Borne AE 1990 Soluble Fc gamma receptor III in human plasma originates from release by neutrophils. J Clin Invest $86: 416-423$

31. Clarkson SB, Bussel JB, Kimberly RP, Valinsky JE, Nachman RL, Unkeless JC 1986 Treatment of refractory immune thrombocytopenic purpura with an anti-Fc gamma-receptor antibody. $N$ Engl J Med 314:1236-1239

32. Haque $\mathrm{KN}$, Zaidi $\mathrm{MH}$, Haque SK, Bahakim $\mathrm{H}$, el-Hazmi M, el-Swailam M 1986 Intravenous immunoglobulin for prevention of sepsis in preterm and low birth weight infants. Pediatr Infect Dis 5:622-625

33. Clapp DW, Kliegman RM, Baley JE, Shenber N, Kyllonen K, Fanaroff AA, Berger M 1989 Use of intravenously administered immune globulin to prevent nosocomial sepsis in low birth weight infants: report of a pilot study. J Pediatr 115:973-978

34. Fischer GW 1988 Immunoglobulin therapy of neonatal group B streptococcal infections: an overview. Pediatr Infect Dis J 7(suppl):13-16 